Article

\title{
Evaluation of the Water-Storage Capacity of Bryophytes along an Altitudinal Gradient from Temperate Forests to the Alpine Zone
}

\author{
Yoshitaka Oishi ${ }^{(D)}$ \\ Center for Arts and Sciences, Fukui Prefectural University, 4-1-1 Kenjojima, Matsuoka, Eiheiji-cho, Yoshida-gun, \\ Fukui 910-1195, Japan; oishiy@fpu.ac.jp; Tel.: +81-76-61-6000
}

Received: 10 May 2018; Accepted: 16 July 2018; Published: 18 July 2018

check for updates

\begin{abstract}
Forests play crucial roles in regulating the amount and timing of streamflow through the water storage function. Bryophytes contribute to this increase in water storage owing to their high water-holding capacity; however, they might be severely damaged by climate warming. This study examined the water storage capacity (WSC) of bryophytes in forests in the mountainous areas of Japan. Sampling plots $\left(100 \mathrm{~m}^{2}\right)$ were established along two mountainous trails at $200-\mathrm{m}$ altitude intervals. Bryophytes were sampled in these plots using $100-\mathrm{cm}^{2}$ quadrats, and their WSC was evaluated according to the maximum amount of water retained in them (WSC-quadrat). The total amount of water in bryophytes within each plot (WSC-plot) was then calculated. The WSC-quadrat was affected by the forms of bryophyte communities (life forms) and their interactions, further influencing soil moisture. The WSC-quadrat did not show any significant trend with altitude, whereas, the highest WSC-plot values were obtained in subalpine forests. These changes to WSC-plot were explained by large differences in bryophyte cover with altitude. As the WSC controlled by the life forms might be vulnerable to climate warming, it can provide an early indicator of how bryophyte WCS and associated biological activities are influenced.
\end{abstract}

Keywords: climate warming; East Asia; forest floor; forest hydrology; subalpine forest

\section{Introduction}

Forests play crucial roles in regulating the amount and timing of streamflow by mitigating the effects of precipitation via their water storage function [1,2]. The influence of afforestation on streamflow has been shown by many studies; for example, afforestation of grasslands and shrublands resulted in a loss of one-third to three-quarters of streamflow on average [3]. These roles contribute to the water cycle in forest ecosystem that has diverse ecological functions, such as a source of water supply, flood and erosion control, conservation of biodiversity, and climate stabilization [4-6].

The storage of water in forests is achieved by the interaction of plant groups with vertical stratification [7]. Forest canopies intercept rainfall and reduce the impact of rain drops on the ground [8]. Under these canopies, epiphytes on trees store rainfall and fog temporarily [9], while the roots of trees and grasses improve the infiltration of soil, reducing runoff and soil erosion [10,11]. In areas with less developed forest canopies, grass and biological soil crusts (assemblages of bryophytes, lichens, algae, cyanobacteria, and fungi) strongly affect the process of water infiltration into the soil, and partly control the amount of run off $[12,13]$.

In recent years, there is serious concern about the changes of water storage in forests because of the influence of climate warming on vegetation [14-16]. The rapid shift in species distribution by the global rise in temperature is evidenced by species both expanding to newly favorable locations and declining in unfavorable areas. The estimated shift of species to higher elevations is at median rate of $11.0 \mathrm{~m}$ per 
decade, while the shift to higher latitudes is estimated at $16.9 \mathrm{~km}$ per decade [17]. Under current climate change scenarios, one-tenth to one-half of global land might be highly or very highly vulnerable [18]. Temperate mixed forests, boreal conifer forests, tundra, and alpine biomes are considered the most vulnerable biomes to these changes [18]. The changes of forest ecosystems in response to climate warming might alter water yield, impacting water supply for human consumption [16].

The response of vegetation to climate warming differs according to plant groups. Among plant groups, serious damage to bryophytes may arise due to their sensitivity to these changes because of their poikilohydric properties [19]. The water content of bryophytes is highly dependent on their external environment, decreasing rapidly when temperature rises and humidity drops $[19,20]$. The decrease in the water content leads to a shorter period of metabolic activity and tissue damage caused by drought stress [20]. As a result, bryophytes, especially those currently growing in environments with low drought stress, are sensitive to climatic warming that causes both thermal and drought stress [20,21].

Although bryophytes are vulnerable to climate warming, they play important roles in increasing the water storage capacity of forest ecosystems [9,22-27]. Because of their poikilohydric properties, bryophytes can retain relatively high amount of water within the community, ranging between approximately $200 \%$ and $3000 \%$ of their dry mass $[25,28,29]$. Their water storage capacity is severely reduced once they are water saturated [9]; however, they contribute towards buffering the influence of rainfall on forest ecosystems, especially at the beginning of rainfall events [9]. This buffering function might be more important as the frequency of heavy rainfall in short term are expected to increase due to climatic change [30]. Regarding the water storage function of bryophytes, this is well documented in epiphytes occupying montane cloud forests [9,22-27]. For example, in tropical cloud forests, epiphytic bryophytes are estimated to store ca. 3-3.5 mm of rainfall $[23,25]$ whereas epiphytes (bryophytes and lichens) store 1.2-1.4 $\mathrm{mm}$ in an old Douglas-fir forest [22]. The contribution of bryophytes to total rainfall interception is estimated to be $6 \%$ in tropical montane forests [24].

Unlike epiphytic bryophytes, the water storage function of forest floor bryophytes (bryophytes on the ground or on logs) is poorly known. Nevertheless, these bryophytes exhibit higher maximum values of water storage when compared to epiphytic bryophytes [22], contributing to the forest water cycle. In addition, the cover of forest floor bryophytes reduces soil temperature, while it improves the retention of soil moisture by decreasing evapotranspiration [31]. Lower soil temperature subsequently limits the decomposition of fresh litter, causing organic carbon to accumulate in the soil [32]. When considering these ecological functions of forest floor bryophytes, it is important to evaluate their water storage capacity to reveal the influence of climate warming on the hydrological processes of forest ecosystems.

In this study, the water storage capacity of bryophytes, including forest floor species, was evaluated in the montane forests of Japan, where high bryophyte diversity is harbored [33,34]. For this purpose, this study focused on the altitudinal patterns of bryophytes because altitude is one of the major factors that determine the behavior of bryophytes in montane forest ecosystems $[35,36]$. The results of this study will advance our understanding of how bryophytes contribute to the hydrological processes in forest ecosystems, which may implicate changes in their water storage function in response to climate warming.

\section{Materials and Methods}

\subsection{Study Site}

The study site is located on the Yatsugatake Mountains, in central Japan (Figure 1). These mountains stretch ca. $30 \mathrm{~km}$ from north to south and $15 \mathrm{~km}$ from east to west. The highest peak is Mt. Akadake $(2899 \mathrm{~m})$. The vegetation is roughly grouped into four types; temperate broadleaved forests (below ca. $1800 \mathrm{~m}$ ), subalpine conifer forests (ca. 1800-2600 m), stone pine forests (ca. 2600-2800 m), and alpine meadows (ca. 2800-2900 m). Annual mean temperature and 
precipitation from 1981 to 2010, measured at the closest weather station (Nobeyama; $1350 \mathrm{~m}$ alt.), were $6.9^{\circ} \mathrm{C}$ and $1439 \mathrm{~mm}$, respectively [37]. The highest temperatures are recorded in August $\left(19.2^{\circ} \mathrm{C}\right)$ and the lowest are in January $\left(-5.3^{\circ} \mathrm{C}\right)$ [38]. Precipitation also changes seasonally; being highest in September (210.5 mm/month) and lowest in December (38.4 mm/month) [38].

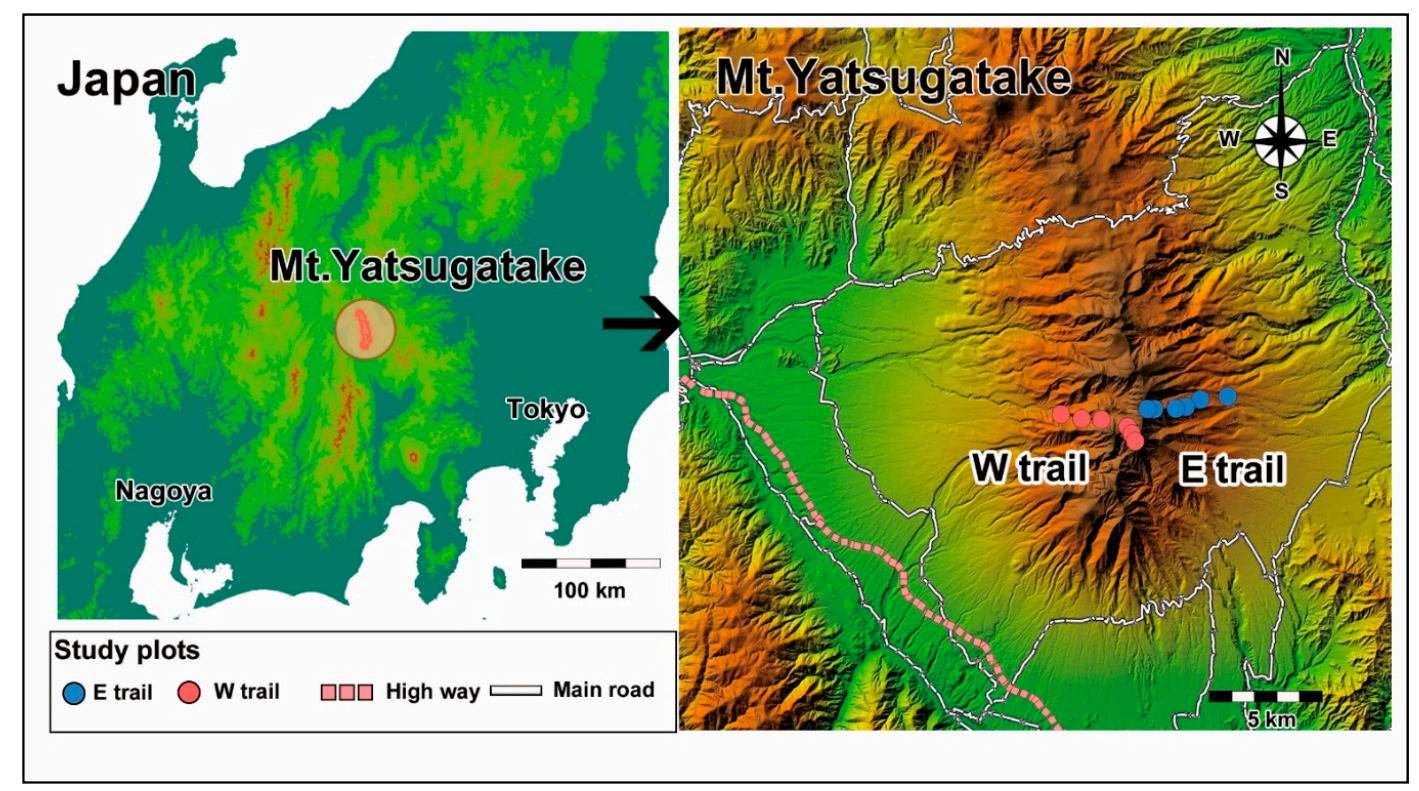

Figure 1. Study site, Mt. Yatsugatake, central Japan. The location of Mt. Yatsugatake is shown by the red circles in the slide on the left. Study plots were established along the E and W trails at 200-m altitude intervals, from 1800 to $2800 \mathrm{~m}$. The left-hand panel was adapted from Figure 1 of Oishi [39]. The right-hand panel was created using global information system data provided by the Ministry of Land and Geospatial Information Authority of Japan.

\subsection{Sampling and Water Storage Capacity}

Twelve $10 \mathrm{~m} \times 10 \mathrm{~m}$ study plots were selected at 200-m altitude intervals from 1800 to $2800 \mathrm{~m}$ along two trails (eastern trail; E trail, western trail; $\mathrm{W}$ trail) extending from the east to the west side of Mt. Yatsugatake (Figure 1). The plot of the $\mathrm{E}$ trail at $1800 \mathrm{~m}$ belongs to temperate-subalpine mixed forests, while the E trail extending from ca. $2000 \mathrm{~m}$ to $2600 \mathrm{~m}$ and the $\mathrm{W}$ trail extending from ca. 1800-2400 m altitude are classified as subalpine forests. Other plots at higher altitudes belong to stone pine forests or alpine meadows. In these study plots, three to four samples of dominant bryophyte communities were collected from each substrate [soil (including humus), rock, logs, and tree trunks] using sampling quadrats $(10 \mathrm{~cm} \times 10 \mathrm{~cm})$. When dominant bryophyte communities consisted of more than one species, the ratios of each species in the collected samples were adjusted to those observed in the field. When the largest bryophyte cover was smaller than $100 \mathrm{~cm} \times 100 \mathrm{~cm}$ on each substrate, this substrate was not included in the sampling. The life forms of sampled species were also recorded according to the life form classification of Bates [40]. To estimate maximum water storage capacity (WSC) of bryophytes under field conditions, sampling was completed during August 2015, when no rain occurred for five consecutive days during the summer. Substrate and the bryophyte cover were measured in these plots by $10 \%$ increments; however, when the cover was less than $10 \%$, they were recorded by $5 \%$ increments. Percentage values of these covers were then transformed to $\mathrm{m}^{2}$ values.

Collected samples were placed in sealed plastic bags to keep their community structure as intact as possible and were transported to the laboratory. The soils, litter, and other small mixed species were cleaned from the samples, and these samples were weighed (fresh weight; Fw). After weighing, the samples were dipped in a water container to represent the state of bryophytes when fully saturated by heavy rainfall. Samples were taken and then placed for $10 \mathrm{~min}$ to remove the extra external water, 
which was not tightly connected with the shoots. Then, these samples were weighed again (saturated weight; Sw). After these procedures, bryophyte samples were oven-dried at $80{ }^{\circ} \mathrm{C}$ for $48 \mathrm{~h}$, and then weighed again (dry weight; Dw). Using Fw and Dw values, two types of water storage capacity (WSC) of bryophytes were calculated: WSC of fresh samples $\left(\right.$ WSC $\left._{\mathrm{f}}\right)$ and WSC of oven-dried samples $\left(W S C_{d}\right) . W_{f}$ represents the possible maximum amount of water absorbed by bryophytes under field conditions. However, dried samples are often used to estimate bryophyte WSC $[9,22,25,27,28]$; therefore, WSC $_{\mathrm{d}}$ was also used for comparison with other studies.

To examine the influence of bryophytes on soil moisture, three soil samples were collected using a soil core sampler $\left(100 \mathrm{~cm}^{3}\right)$ in each plot. The collected soil samples were preserved in sealed plastic bags and were weighed in the laboratory. After oven-drying at $80^{\circ} \mathrm{C}$ for $48 \mathrm{~h}$, these oven dried samples were weighed again. The differences in weight before and after the soil samples were dried were used as the soil moisture $\left(\mathrm{g} / 100 \mathrm{~cm}^{3}\right)$.

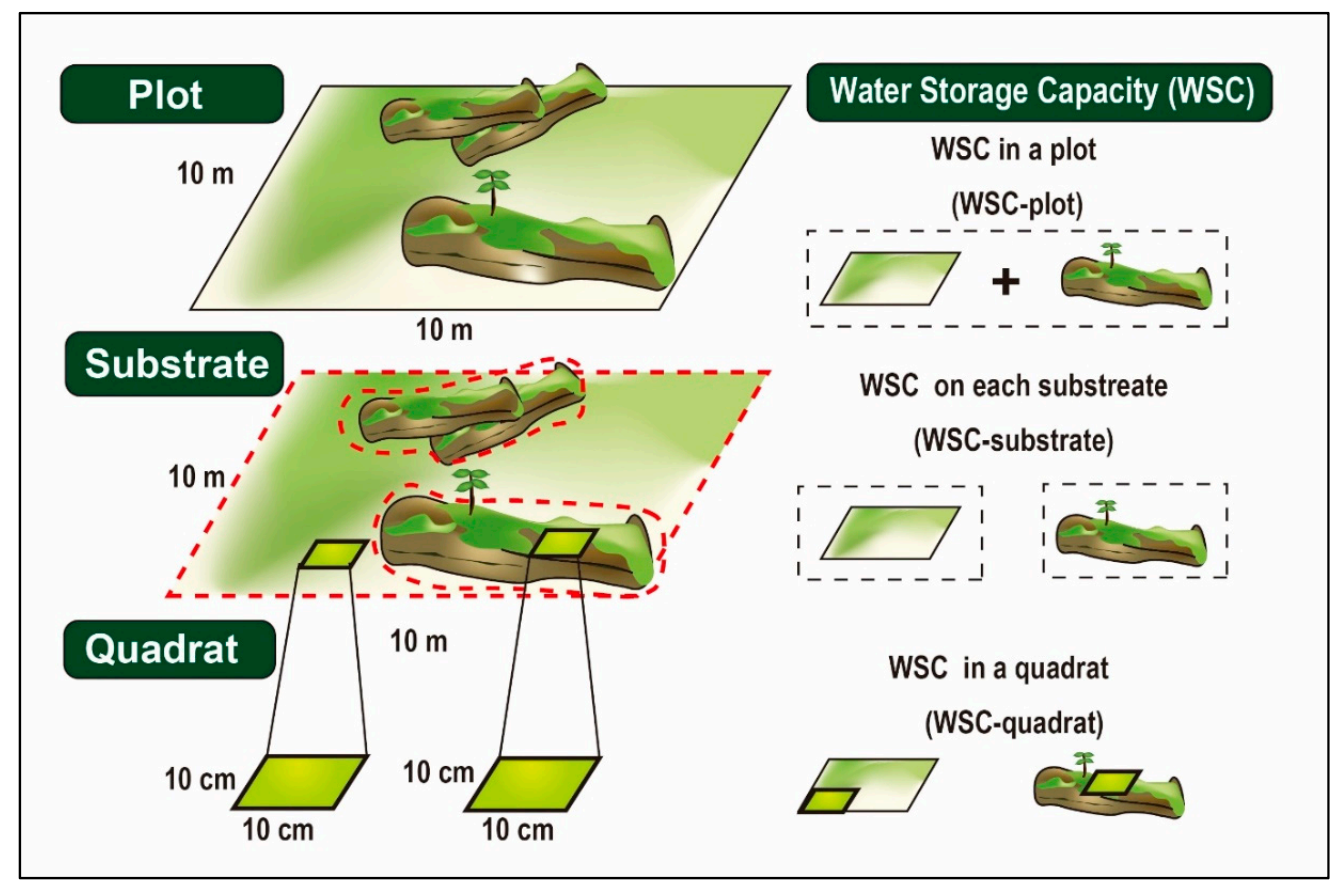

Figure 2. Schematic showing the hieratical evaluation of the water storage capacity of bryophytes.

\subsection{Water Storage Capacity at Quadrat, Substrate, and Plot Scales}

Bryophyte WSC was assessed hierarchically at three scales: quadrat, substrate, and plot scales (Figure 2). The values of $\mathrm{WSC}_{\mathrm{f}} / \mathrm{WSC}_{\mathrm{d}}$ at sampling quadrats $\left(\mathrm{WSC}_{\mathrm{f}}\right.$-quadrat/WSC $\mathrm{d}_{\mathrm{d}}$-quadrat; $\mathrm{g} / 100 \mathrm{~cm}^{2}$ ) were calculated by subtracting Fw/Dw from Sw as follows:

$$
\begin{aligned}
& \text { WSC }_{\mathrm{f}} \text {-quadrat }\left(\mathrm{g} / 100 \mathrm{~cm}^{2}\right)=S w-F W \\
& \text { WSC }_{d} \text {-quadrat }\left(g / 100 \mathrm{~cm}^{2}\right)=S w-D w .
\end{aligned}
$$

Using these values, the total $\mathrm{WSC}_{\mathrm{f}} / \mathrm{WSC}_{\mathrm{d}}$ of bryophytes on each substrate within a plot (WSC $_{\mathrm{f}}$-substrate/WSC $\mathrm{d}_{\mathrm{d}}$-substrate) was estimated according to the following equations:

$$
\begin{aligned}
& \text { WSC }_{\mathrm{f}} \text {-substrate }(\mathrm{K})\left(\mathrm{L} / 100 \mathrm{~m}^{2}\right)=\mathrm{WSC}_{\mathrm{f}} \text {-quadrat }(\mathrm{K}) \times \operatorname{Cov}(\mathrm{K}) \times 10^{-1} \\
& \text { WSC }_{\mathrm{d}} \text {-substrate }(\mathrm{K})\left(\mathrm{L} / 100 \mathrm{~m}^{2}\right)=\mathrm{WSC}_{\mathrm{d}} \text {-quadrat }(\mathrm{K}) \times \operatorname{Cov}(\mathrm{K}) \times 10^{-1}
\end{aligned}
$$


where, $\mathrm{K}$ = substrate types (soil, rocks, logs, and tree trunk) and Cov $(\mathrm{K})=$ total bryophyte cover on substrate $(\mathrm{K})$.

Then, total $\mathrm{WSC}_{\mathrm{f}} / \mathrm{WSC}_{\mathrm{d}}$ within each plot $\left(\mathrm{WSC}_{\mathrm{f}}\right.$-plot/WSC -plot; $\mathrm{L} / 100 \mathrm{~m}^{2}$ ) was evaluated using the values of $\mathrm{WSC}_{\mathrm{f}}$-substrate/ $\mathrm{WSC}_{\mathrm{d}}$-substrate as follows:

$$
\begin{aligned}
\mathrm{WSC}_{\mathrm{f} \text {-plot }}\left(\mathrm{L} / 100 \mathrm{~m}^{2}\right) & =\sum_{\mathrm{k}=1}^{4}\left[\mathrm{WSC}_{\mathrm{f} \text {-substrate }}(\mathrm{K})\right] \\
\mathrm{WSC}_{\text {d-plot }}\left(\mathrm{L} / 100 \mathrm{~m}^{2}\right) & =\sum_{\mathrm{k}=1}^{4}\left[\mathrm{WSC}_{\mathrm{d} \text {-substrate }}(\mathrm{K})\right]
\end{aligned}
$$

where, $\mathrm{k}$ means substrate type $(\mathrm{k}=1$; soil, $\mathrm{k}=2$; rocks, $\mathrm{k}=3$; logs, $\mathrm{k}=4$; tree trunk).

\subsection{Modeling}

The difference in bryophyte WSC-quadrat between substrate types and between life form types was examined by $t$-test or Tukey's multiple comparison test. The influence of forest floor bryophytes on soil moisture was then examined by Pearson product-moment correlation between the WSC-quadrat values of bryophytes on soil and soil moisture. As the texture of soils largely differed between alpine and below alpine areas, the alpine data were not included in the calculation.

At substrate scales, the values of bryophyte WSC can be influenced by environmental (e.g., substrate type and cover) and ecological factors (e.g., types of bryophyte community). To reveal these influences, linear models were used that correlated the values of $\mathrm{WSC}_{\mathrm{f}}$-substrate/WSC $\mathrm{d}^{-}$ substrate with these variables. This modeling was performed for fresh and dried bryophyte samples, respectively. The environmental and ecological variables used in the modeling were substrate type, cover of each substrate within a plot $\left(\mathrm{m}^{2}\right), \mathrm{Fw} / \mathrm{Dw}, \mathrm{WSC}_{\mathrm{f}}$-quadrat $/ \mathrm{WSC}_{\mathrm{d}}$-quadrat, total bryophyte cover on each substrate $\left(\mathrm{m}^{2}\right)$, and water uptake strategies of the dominant bryophyte communities (ectohydric, endohydric, and mixed types). The types of substrate and water uptake strategies were adopted as categorical variables. The best-fit models were identified using the step Akaike information criterion (AIC) function. For these models, only variables that were significantly correlated with $\mathrm{WSC}_{\mathrm{f}}$-substrate/ $\mathrm{WSC}_{\mathrm{d}}$-substrate were used. In addition to these models, linear mixed models were constructed with the $\mathrm{E} / \mathrm{W}$ trails as nested variables to reflect the influence of each trail on bryophyte WSC. The best-fit models were selected using the same procedures as for the linear models. All calculations were performed with R software [41].

\section{Results}

\subsection{Water Storage Capacity of Bryophyte Communities at the Quadrat Scale}

\subsubsection{Comparison of Water Storage Capacity of Bryophyte Communities}

In the 12 study plots, bryophyte cover larger than $100 \mathrm{~cm} \times 100 \mathrm{~cm}$ was only found on the soil and on logs; hence, the bryophyte communities on these substrates were sampled. In total, 62 samples were collected from these plots and 16 bryophyte communities consisting of 11 bryophyte species were recorded (Table 1). These species included Codriophorus fasicularis (Hedw.) Bednarek-Ochyra \& Ochyra (Cod fas), Dicranum majus Turner (Dic maj), Dicranum nipponense Besch. (Dic nip), Heterophyllium affine (Hook.) M. Fleisch. (Het aff), Hylocomium splendens (Hedw.) Schimp. (Hyl spl), Hypnum plicatulum (Lindb.) A. Jaeger (Hyp pli), Nowellia curvifolia (Dicks.) Mitt. (Now cur), Pleurozium schreberi (Willd. ex Brid.) Mitt. (Ple shr), Pogonatum contortum (Menzies ex Brid.) Lesq. (Pog con), Pogonatum japonicum Sull. \& Lesq. (Pog jap), and Rigodiadelphus robustus (Lindb.) Nog. (Rig rob). Among the 16 bryophyte communities, several small liverworts (e.g., Cephaloziea sp.) were often found; however, their influence on the WSC of these bryophyte communities was not considered because they represented low biomass and a small number of shoots. The life form types recorded in the samples 
were tall turfs $(\mathrm{T})$, large cushions $(\mathrm{Cu})$, smooth mats $(\mathrm{Sm})$, rough mats $(\mathrm{Rm})$, thread-like forms $(\mathrm{Tl})$, and wefts $(\mathrm{W})$.

The bryophyte communities were grouped into three types by the number of species. Bryophyte communities consisted of one species (e.g., Cor fas), two species (e.g., Dic maj-Hyl spl), or three species (e.g., Dic maj-Het aff-Ple shr). Among the collected species, Hyl spl and Ple shr had the highest occurrence in these dominant communities (Hyl spl; 11 times, Ple shr; 11 times), ranging from 1800 to $2600 \mathrm{~m}$ altitude. The average \pm standard deviation $(S D)$ of $\mathrm{Fw}, \mathrm{Dw}$, and $\mathrm{Sw}$ were $13.78 \pm 7.91,4.98 \pm$ 2.86 , and $35.16 \pm 15.46 \mathrm{~g} / 100 \mathrm{~cm}^{2}$, respectively. Using these values, $\mathrm{WSC}_{\mathrm{f}}$-quadrat/ $\mathrm{WSC}_{\mathrm{d}}$-quadrat was calculated. The values of $\mathrm{WSC}_{\mathrm{f}}$-quadrat were $19.72 \pm 9.10 \mathrm{~g} / 100 \mathrm{~cm}^{2}$ for the soil and $23.69 \pm 11.94$ $\mathrm{g} / 100 \mathrm{~cm}^{2}$ for logs. The higher $\mathrm{WSC}_{\mathrm{f}}$-quadrat values were measured in Pog jap, Cor fac, Hyl spl-Ple shr, and Rig rob-Ple shr communities (average values; $>30 \mathrm{~g} / 100 \mathrm{~cm}^{2}$ ), while Hyl spl-Ple shr communities also had larger variation in these values, ranging from 12.21 to $36.00 \mathrm{~g} / 100 \mathrm{~cm}^{2}$ on average, across substrates (Table 1). The values of the $\mathrm{WSC}_{\mathrm{d}}$-quadrat demonstrated similar trends to those of the WSC $_{\mathrm{f}}$-quadrat and were significantly correlated with those of the $\mathrm{WSC}_{\mathrm{f}}$-quadrat $(r=0.915, n=62, p<$ 0.01). The values of the $W_{S C} C_{d}$-quadrat were $29.80 \pm 13.11 \mathrm{~g} / 100 \mathrm{~cm}^{2}$ for the soil and were $30.72 \pm$ $13.11 \mathrm{~g} / 100 \mathrm{~cm}^{2}$ for logs.

Table 1. Water storage capacity of dominant bryophyte communities at the quadrat scale $\left(100 \mathrm{~cm}^{2}\right)$, and their total cover on each substrate within the study plots.

\begin{tabular}{|c|c|c|c|c|c|c|c|c|}
\hline $\begin{array}{l}\text { Altitude } \\
(\mathrm{m})\end{array}$ & Trail $^{1}$ & $\begin{array}{l}\text { Bryophyte Community } \\
\text { (Life form Type) }\end{array}$ & $n$ & $\begin{array}{c}\text { FW } \\
\left(\mathrm{g} / 100 \mathrm{~cm}^{2}\right)\end{array}$ & $\begin{array}{c}\text { DW } \\
\left(\mathrm{g} / 100 \mathrm{~cm}^{2}\right)\end{array}$ & $\begin{array}{l}\left.W_{\left(g / 100 c_{f}-q\right.} c^{2}\right)\end{array}$ & $\begin{array}{l}\left.W_{\left(g / 100 c_{d}-q\right.} c^{2}\right)\end{array}$ & $\begin{array}{c}\text { Cover } \\
\left(\mathrm{m}^{2} / \text { plot }\right)\end{array}$ \\
\hline \multicolumn{9}{|c|}{ Soil } \\
\hline 1800 & E & Dic nipn-Pog con (T-T: T) & 3 & $8.05 \pm 1.37$ & $2.80 \pm 0.39$ & $13.79 \pm 4.04$ & $19.04 \pm 4.17$ & 5 \\
\hline 2000 & E & Hyl spl-Ple shr (W-W: W) & 3 & $9.28 \pm 2.97$ & $3.54 \pm 0.74$ & $20.27 \pm 5.86$ & $26.03 \pm 8.08$ & 7 \\
\hline 2200 & E & Pog con-Hyl spl (T-W) & 3 & $17.12 \pm 1.07$ & $5.28 \pm 0.96$ & $14.11 \pm 4.08$ & $25.95 \pm 3.93$ & 24 \\
\hline 2400 & E & $\operatorname{Pog} \operatorname{con}(\mathrm{T})$ & 3 & $9.71 \pm 1.47$ & $3.38 \pm 0.47$ & $10.18 \pm 1.96$ & $16.51 \pm 2.47$ & 32 \\
\hline 2600 & E & Pog jap $(\mathrm{T})$ & 3 & $38.96 \pm 9.52$ & $14.81 \pm 3.65$ & $32.89 \pm 3.94$ & $57.03 \pm 7.08$ & 24 \\
\hline 2800 & E & $\begin{array}{c}\text { Dic maj-Het aff-Ple shr } \\
(\mathrm{T}-\mathrm{Sm}-\mathrm{W})\end{array}$ & 3 & $7.21 \pm 4.47$ & $2.53 \pm 1.47$ & $12.11 \pm 7.95$ & $16.79 \pm 10.32$ & 10 \\
\hline 1800 & $\mathrm{~W}$ & Hyl spl-Ple shr (W-W: W) & 3 & $15.90 \pm 5.37$ & $5.23 \pm 0.19$ & $24.78 \pm 5.40$ & $35.47 \pm 0.20$ & 63 \\
\hline 2000 & $\mathrm{~W}$ & $\operatorname{Hyl} \operatorname{spl}(\mathrm{W})$ & 3 & $10.03 \pm 0.96$ & $4.57 \pm 0.52$ & $24.39 \pm 6.44$ & $30.18 \pm 6.90$ & 51 \\
\hline 2200 & $\mathrm{~W}$ & $\begin{array}{l}\text { Pog jap-Hyl spl-Ple shr } \\
\text { (T-W-W: T-W) }\end{array}$ & 3 & $18.83 \pm 6.51$ & $5.56 \pm 1.75$ & $16.45 \pm 9.42$ & $29.73 \pm 8.59$ & 40 \\
\hline 2400 & $\mathrm{~W}$ & $\begin{array}{c}\text { Pog jap-Dic maj-Ple shr } \\
\text { (T-T-W: T-W) }\end{array}$ & 3 & $11.69 \pm 6.43$ & $3.90 \pm 1.83$ & $16.86 \pm 10.54$ & $24.65 \pm 14.56$ & 48 \\
\hline 2600 & $\mathrm{~W}$ & Dic maj-Hyl spl (T-W) & 3 & $15.12 \pm 3.90$ & $4.53 \pm 1.16$ & $19.79 \pm 3.75$ & $30.38 \pm 6.21$ & 50 \\
\hline 2800 & $\mathrm{~W}$ & $\operatorname{Cor} f a s(\mathrm{Cu})$ & 3 & $22.24 \pm 3.00$ & $7.34 \pm 1.85$ & $31.02 \pm 11.71$ & $45.92 \pm 7.03$ & 5 \\
\hline \multicolumn{9}{|c|}{ Logs } \\
\hline 2000 & E & Hyl spl-Ple shr (W-W: W) & 3 & $6.20 \pm 0.73$ & $2.91 \pm 0.51$ & $12.21 \pm 5.60$ & $15.49 \pm 5.59$ & 3 \\
\hline 2200 & E & Het aff-Ple shr $(\mathrm{Sm}-\mathrm{W})$ & 3 & $14.85 \pm 3.33$ & $4.87 \pm 0.47$ & $25.51 \pm 2.24$ & $35.49 \pm 1.78$ & 32 \\
\hline 2400 & $\mathrm{E}$ & Now cur-Ple shr (Tl-W) & 3 & $5.45 \pm 2.16$ & $2.00 \pm 1.37$ & $10.71 \pm 7.20$ & $14.16 \pm 8.00$ & 8 \\
\hline 2600 & E & Rig rob-Ple shr (Rm-W) & 3 & $13.35 \pm 2.62$ & $6.52 \pm 0.08$ & $35.47 \pm 9.30$ & $42.30 \pm 8.77$ & 4 \\
\hline 1800 & $\mathrm{~W}$ & $\begin{array}{l}\text { Hyp pli-Hyl spl-Ple shr } \\
\text { (Sm-W-W: Sm-W) }\end{array}$ & 4 & $12.87 \pm 3.75$ & $5.29 \pm 1.05$ & $29.20 \pm 10.44$ & $36.78 \pm 12.15$ & 8 \\
\hline 2000 & W & Het aff-Hyl spl (W-W: W) & 4 & $9.05 \pm 1.87$ & $3.24 \pm 0.69$ & $18.59 \pm 8.12$ & $24.40 \pm 5.64$ & 24 \\
\hline 2200 & $\mathrm{~W}$ & Hyl spl-Ple shr (W-W: W) & 3 & $17.40 \pm 2.88$ & $5.38 \pm 1.67$ & $21.66 \pm 11.15$ & $33.68 \pm 7.42$ & 40 \\
\hline 2400 & W & Hyl spl-Ple shr (W-W: W) & 3 & $13.84 \pm 3.90$ & $6.32 \pm 1.20$ & $36.00 \pm 16.55$ & $43.52 \pm 17.07$ & 16 \\
\hline
\end{tabular}

${ }^{1}$ Trails are represented in Figure 1. Abbreviations are as follows: $n$; number of quadrats, FW; fresh weight, DW; dry weight, WSC $_{\mathrm{f}}$-q; water storage capacity of fresh samples within a quadrat, WSC $_{\mathrm{d}}$-q; water storage capacity of dried samples within a quadrat, Cover; total cover on each substrate within a plot, E; E trail, W; W trail, Cod fas; Codriophorus fasicularis, Dic maj; Dicranum majus, Dic nip; Dicranum nipponense, Het aff; Heterophyllium affine, Hyl spl; Hylocomium splendens, Hyp pli; Hypnum plicatulum, Now cur; Nowellia curvifolia, Ple shr; Pleurozium schreberi, Pog con; Pogonatum contortum, Pog jap; Pogonatum japonicum, Rig rob; Rigodiadelphus robustus, T; tall turfs, Cu; large cushions, $\mathrm{Rm}$; rough mats, Sm; smooth mats, Tl; thread-like forms, and W; wefts.

To examine the influence of life forms on bryophyte WSC, the WSC of each life form type was calculated (Table 2). In fresh samples, higher WSC was measured in Rm-W, followed by $\mathrm{Cu}, \mathrm{Sm}-\mathrm{W}$, and $\mathrm{W}$ forms. In contrast, Tl-W, T-Sm-W, and T-W forms had lower values. The dry samples showed similar results. Using multiple comparison, significant differences were found between $\mathrm{Rm}-\mathrm{W}$ and $\mathrm{Tl}-\mathrm{W}$ in fresh samples and between $\mathrm{Cu}$ and $\mathrm{Tl}-\mathrm{W}$ in dry samples $(p<0.05)$. 
Table 2. Water storage capacity of bryophyte communities at the quadrat scale $\left(100 \mathrm{~cm}^{2}\right)$ among life form types.

\begin{tabular}{|c|c|c|c|c|c|c|c|c|}
\hline Life Form & $\mathbf{T}$ & $\mathrm{Cu}$ & $\mathbf{W}$ & Rm-W & Sm-W & $T-W$ & Tl-W & T-Sm-W \\
\hline$n$ & 9 & 3 & 21 & 3 & 8 & 12 & 3 & 3 \\
\hline \multicolumn{9}{|c|}{$W_{S C}-q\left(g / 100 \mathrm{~cm}^{2}\right)$} \\
\hline Average & 18.95 & 31.02 & 23.55 & 35.47 & 23.89 & 16.80 & 10.71 & 12.11 \\
\hline$S D$ & 10.99 & 11.71 & 9.98 & 9.30 & 9.45 & 6.8 & 7.20 & 7.95 \\
\hline Significance & $\mathrm{ab}$ & $\mathrm{ab}$ & $\mathrm{ab}$ & $\mathrm{b}$ & $\mathrm{ab}$ & $a b$ & $\mathrm{a}$ & $\mathrm{ab}$ \\
\hline \multicolumn{9}{|c|}{$W C_{d}-q\left(g / 100 \mathrm{~cm}^{2}\right)$} \\
\hline Average & 30.86 & 45.92 & 31.40 & 42.30 & 30.59 & 27.68 & 14.16 & 16.79 \\
\hline$S D$ & 20.12 & 7.03 & 10.94 & 8.77 & 10.34 & 8.26 & 8.01 & 10.32 \\
\hline Significance & $\mathrm{ab}$ & $\mathrm{b}$ & $a b$ & $a b$ & $a b$ & $a b$ & $\mathrm{a}$ & $a b$ \\
\hline
\end{tabular}

Abbreviations are as follows: T; tall turfs, $\mathrm{Cu}$; large cushions, W; Wefts, $\mathrm{Rm}$; rough mats, $\mathrm{Sm}$; smooth mats, Tl; thread-like-forms, $n$; number of quadrats, $\mathrm{WSC}_{\mathrm{f}}$-q; water storage capacity of fresh samples within a quadrat, $\mathrm{WSC}_{\mathrm{d}}-\mathrm{q}$; water storage capacity of dried samples within a quadrat, $S D$; standard deviation, Significance; different letters show significant differences by multiple comparisons $(p<0.05)$.

\subsubsection{Water Storage Capacity of Bryophytes and Soil Moisture}

The influence of bryophyte WSC on soil moisture was examined using the data except for alpine areas. The values of soil moisture were $13.82 \pm 5.27 \mathrm{~g} / 100 \mathrm{~cm}^{3}$ (Average $\pm S D$ ). These soil moistures were significantly and positively correlated with $\mathrm{WSC}_{\mathrm{d}}$-quadrat $(n=9, r=0.778, p=0.014)$ and were strongly, but not significantly, correlated with $\mathrm{WSC}_{\mathrm{f}}$-quadrat $(n=9, r=0.613, p=0.079)$.

\subsubsection{Altitudinal Patterns of Water Storage Capacity of Bryophyte Communities at the Quadrat Scale}

The values of $\mathrm{WSC}_{\mathrm{f}}$-quadrat/WSC -quadrat were compared in relation to substrate type and altitude. The differences in $\mathrm{WSC}_{\mathrm{f}}$-quadrat between the soil and logs were not statistically significant (WSC $_{\mathrm{f}}$-quadrat; $t$-values $=1.486, d f=60, p=0.143 / \mathrm{WSC}_{\mathrm{d}}$-quadrat; $t$-values $=0.270, d f=60$, $p=0.788)$. Furthermore, the changes in the $\mathrm{WSC}_{\mathrm{f}}$-quadrat/ $\mathrm{WSC}_{\mathrm{d}}$-quadrat with altitude were also not significant for the soil or logs (Figure 3). The Pearson correlation coefficient between WSC $_{\mathrm{f}}$-quadrat $/ \mathrm{WSC}_{\mathrm{d}}$-quadrat and altitude on soil was $0.118(n=62, p=0.43) / 0.227(n=62, p=0.18)$, while that on logs was $0.209(n=62, p=0.31) / 0.193(n=62, p=0.35)$.

\subsection{Water Storage Capacity of Bryophyte Communities on Each Substrate}

Bryophyte cover was recorded on each substrate to calculate $\mathrm{WSC}_{\mathrm{f}}$-substrate/WSC $\mathrm{W}_{\mathrm{d}}$-substrate. Bryophyte cover differed greatly among study plots. The average and $S D$ of total bryophyte cover within each plot was $24.70 \pm 18.86 \mathrm{~m}^{2} / 100 \mathrm{~m}^{2}$. The cover showed the highest values in subalpine forests for both $\mathrm{E}$ and $\mathrm{W}$ trails and on the soil and logs (Table 1). The E trail had the highest values at $2400 \mathrm{~m}$ on soil and at $2200 \mathrm{~m}$ on logs, whereas the $\mathrm{W}$ trail had the highest value at $1800 \mathrm{~m}$ on soil and at $2200 \mathrm{~m}$ on logs. Then, the values of $\mathrm{WSC}_{\mathrm{f}}$-substrate $/ \mathrm{WSC}_{\mathrm{d}}$-substrate were calculated according to Equation (3) and (4) for each substrate. The resulting values of $\mathrm{WSC}_{\mathrm{f}}$-substrate on soil were $60.02 \pm 46.86\left(\mathrm{~L} / 100 \mathrm{~m}^{2}\right)$, while those on logs were $26.63 \pm 31.34\left(\mathrm{~L} / 100 \mathrm{~m}^{2}\right)$. Using these values, linear models for the $\mathrm{WSC}_{\mathrm{f}}$-substrate/ $\mathrm{WSC}_{\mathrm{d}}$-substrate were constructed based on the environmental and ecological variables. Among these variables, only bryophyte cover was significantly correlated with the values of the $\mathrm{WSC}_{\mathrm{f}}$-plot/ $\mathrm{WSC}_{\mathrm{d}}$-plot. Hence, this variable was adopted as an explanatory variable for the linear models. The constructed models for both $\mathrm{WSC}_{\mathrm{f}}$-substrate $(\mathrm{Y}=2.101 \mathrm{X}-1.395$, $\left.R^{2}=0.856\right)$ and $\mathrm{WSC}_{\mathrm{d}}$-substrate $\left(\mathrm{Y}=3.088 \mathrm{X}-2.167, R^{2}=0.866\right)$ fitted well. In comparison, no significant linier mixed models were constructed for each variable. 

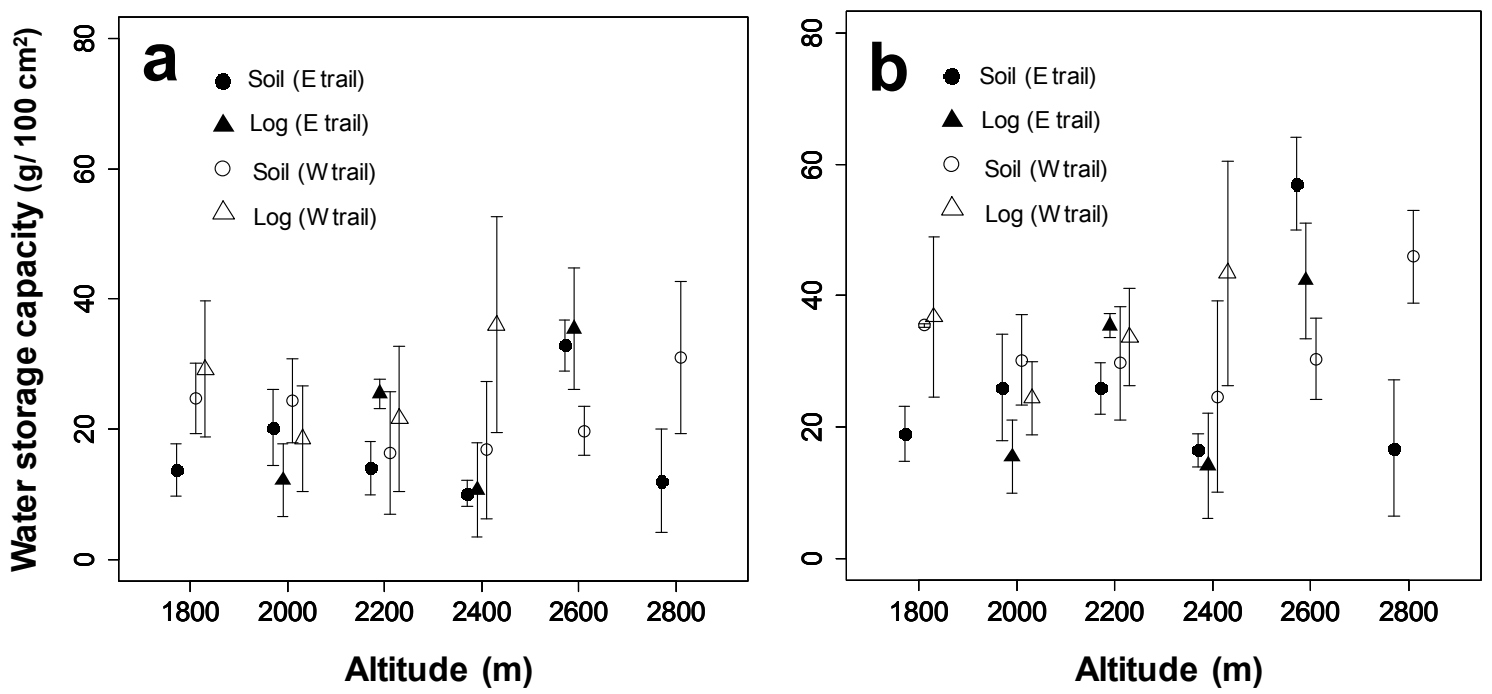

Figure 3. Changes to the water storage capacity of bryophyte communities at the quadrat scale with respect to altitude: (a) fresh samples and (b) dry samples; the error bar indicates standard deviation.

\subsection{Water Storage Capacity of Bryophyte Communities per Plot}

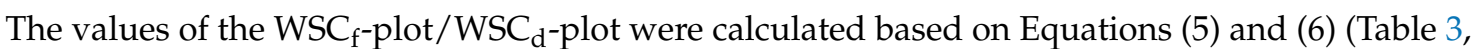
Figure 4). The values of the $\mathrm{WSC}_{\mathrm{f}}$-plot (Average $\pm \mathrm{SD}$ ) were $86.71 \pm 35.90 \mathrm{~L} / 100 \mathrm{~m}^{2}$ (equivalent to the increase of $0.8671 \pm 0.3590 \mathrm{~mm}$ of rainfall interception), while those of the $\mathrm{WSC}_{\mathrm{d}}$-plot were $123.51 \pm 52.59 \mathrm{~L} / 100 \mathrm{~m}^{2}(=1.2351 \pm 0.5259 \mathrm{~mm})$. Both $\mathrm{WSC}_{\mathrm{f}}$-plot/WSC $\mathrm{C}_{\mathrm{d}}$-plot of E trail and W trail had the highest values in subalpine forests; however, the altitude of the plots with the highest WSC values differed for fresh and dry samples. The $\mathrm{WSC}_{\mathrm{f}}$-plot along the $\mathrm{E}$ trail had the highest values at $2200 \mathrm{~m}$ $\left(115.51 \mathrm{~L} / 100 \mathrm{~m}^{2}\right)$, while the highest value of the WSC $_{\mathrm{d}}$-plot was observed at $2600 \mathrm{~m}\left(153.81 \mathrm{~L} / 100 \mathrm{~m}^{2}\right)$. The values of the $\mathrm{WSC}_{\mathrm{f}}$-plot along the $\mathrm{W}$ trail were highest at $1800 \mathrm{~m}\left(179.45 \mathrm{~L} / 100 \mathrm{~m}^{2}\right)$, whereas the WSC $_{\mathrm{d}}$-plot values were highest at $2200 \mathrm{~m}\left(253.60 \mathrm{~L} / 100 \mathrm{~m}^{2}\right)$.

Regarding the changes in the $\mathrm{WSC}_{\mathrm{f}}$-plot/WSC $\mathrm{W}_{\mathrm{d}}$-plot along the altitudinal gradient, the $\mathrm{WSC}_{\mathrm{f}}$-plot data on the $\mathrm{E}$ trail fitted a negative quadratic curve $\left(\mathrm{Y}=-2.87 \times 10^{-4} \mathrm{X}^{2}+1.34 \mathrm{X}-1494.51, R^{2}=0.510\right)$, while that on the $\mathrm{W}$ trail was fitted by liner regression $\left(\mathrm{Y}=-1.49 \times 10^{-1} \mathrm{X}+468.59, R^{2}=0.841\right)$. Similarly, the $\mathrm{WSC}_{\mathrm{d}}$-plot data on trails $\mathrm{E}$ and $\mathrm{W}$ were fitted by the negative quadratic curve $(\mathrm{Y}=-3.73$ $\left.\times 10^{-4} X^{2}+1.77 \mathrm{X}-1979.54, R^{2}=0.515\right)$ and by the linear regression $\left(\mathrm{Y}=-2.00 \times 10^{-1} \mathrm{X}+639.25\right.$, $\left.R^{2}=0.747\right)$, respectively.

Table 3. Bryophyte water storage capacity per plot $\left(100 \mathrm{~m}^{2}\right)$.

\begin{tabular}{|c|c|c|c|c|}
\hline \multirow[b]{2}{*}{ Altitude (m) } & \multicolumn{2}{|c|}{ E Trail } & \multicolumn{2}{|c|}{ W Trail } \\
\hline & $\begin{array}{l}\text { WSC } \mathrm{f}_{\mathrm{f}}-\text { Plot } \\
\left(\mathrm{L} / 100 \mathrm{~m}^{2}\right)\end{array}$ & $\begin{array}{l}\text { WSC }_{d}-\text { Plot } \\
\left(\mathrm{L} / 100 \mathrm{~m}^{2}\right)\end{array}$ & $\begin{array}{l}\text { WSC }_{\mathrm{f}}-\text { Plot } \\
\left(\mathrm{L} / 100 \mathrm{~m}^{2}\right)\end{array}$ & $\begin{array}{l}\mathrm{WSC}_{\mathrm{d}} \text {-Plot } \\
\left(\mathrm{L} / 100 \mathrm{~m}^{2}\right)\end{array}$ \\
\hline 1800 & 6.895 & 9.522 & 179.453 & 252.866 \\
\hline 2000 & 17.853 & 22.850 & 168.982 & 212.466 \\
\hline 2200 & 115.507 & 133.275 & 152.469 & 253.600 \\
\hline 2400 & 40.459 & 64.939 & 138.523 & 187.947 \\
\hline 2600 & 93.133 & 153.808 & 98.967 & 151.917 \\
\hline 2800 & 12.107 & 16.790 & 15.508 & 22.958 \\
\hline Average $\pm S D$ & $47.77 \pm 41.89$ & $66.73 \pm 57.31$ & $\begin{array}{c}125.65 \pm \\
55.53\end{array}$ & $180.29 \pm 78.84$ \\
\hline
\end{tabular}

WSC $_{\mathrm{f}}$-plot; water storage capacity of fresh samples in a plot, $\mathrm{WSC}_{\mathrm{d}}$-plot; water storage capacity of dried samples in a plot, $S D$; standard deviation. 

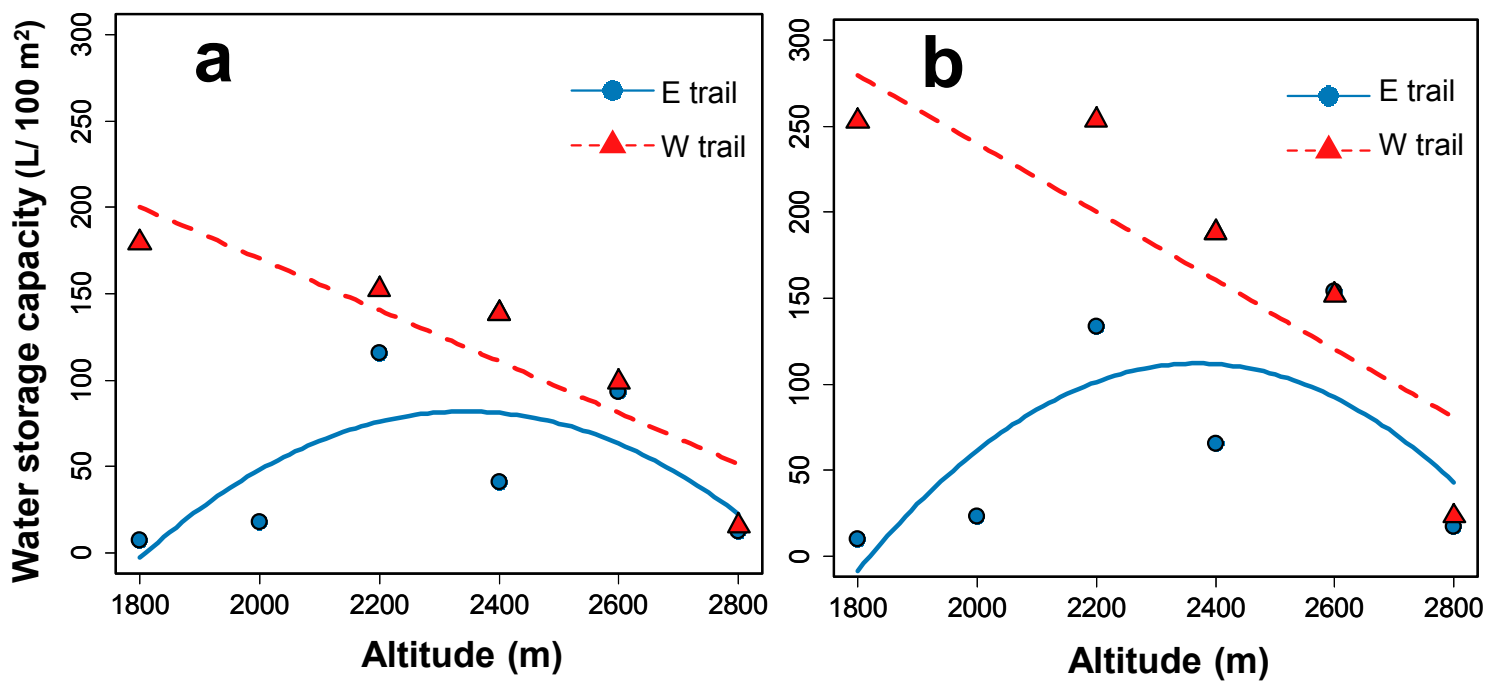

Figure 4. Change to water storage capacity of bryophyte communities within each plot along an altitudinal gradient. (a) Fresh samples, (b) Dry samples.

\section{Discussion}

The WSC quadrat of bryophytes was influenced by the life form types and their interactions, further affecting soil moisture; however, it did not vary with altitude or exhibit significant differences between the substrate types. At the plot scale, the WSC plot significantly correlated with bryophyte cover, with the highest in subalpine forests.

\subsection{Water Storage Capacity at the Quadrat Scale}

Comparison of the $\mathrm{WSC}_{\mathrm{f}}$-quadrat/WSC $\mathrm{d}_{\mathrm{d}}$-quadrat showed higher values in $\mathrm{Hyl}$ spl-Ple shr, Ple shr-Rig rob, Pog jap, and Cor fac communities (Table 1). These results are explained by the community structure of bryophytes. Bryophytes forming compact mats had higher WSC because the spaces between individual shoots retain additional external water [29]. In the plots of the present study, these compact mats were formed by weft-forming mosses (W form; Hyl spl and Ple shr) and large cushion moss ( $\mathrm{Cu}$ form; Cor fas), which contributed to the higher values of the $\mathrm{WSC}_{\mathrm{f}}$-quadrat/ $\mathrm{WSC}_{\mathrm{d}}$-quadrat. In comparison, the community of Pog jap forms tall turfs ( $\mathrm{T}$ form) that physically increases the amount of water held in these communities. Regarding the Hyl spl-Ple shr community, this moss community had large differences in the $\mathrm{WSC}_{\mathrm{f}}$-quadrat $/ \mathrm{WSC}_{\mathrm{d}}$-quadrat, ranging from 12.21-36.00/15.49-43.52 g/100 $\mathrm{cm}^{2}$. These results are attributed to difference in compactness or shoot density, which are reflected by the wider range of their FW/DW values $\left(6.20-17.40 / 2.91-6.32 \mathrm{~g} / 100 \mathrm{~cm}^{2}\right)$.

Some combinations of life forms ( $\mathrm{T}-\mathrm{W}$ and $\mathrm{T}-\mathrm{Sm}-\mathrm{W}$ forms) had lower WSC values on average than those of less mixed or single forms ( $\mathrm{T}$ or $\mathrm{W}$ and $\mathrm{T}$ or $\mathrm{Sm}-\mathrm{W}$ forms), despite there being no differences among the species in these communities (Table 2). The decreased WSC of these mixed life forms could be explained by their poor ability to form tight communities with neighboring species, due to differences in the characteristics of the life forms. The upright $\mathrm{T}$ form is largely different from that of the creeping Sm and $\mathrm{W}$ forms in their morphology. Moreover, the $\mathrm{T}$ form species include endohydric bryophytes (Polytrichaceae; P. controtum and P. japonium), which develop internal water conducting tissues and mainly absorb water from substrates [42]. In contrast, the Sm and W forms are ectohydric species without such conducting tissues, and exclusively rely on external capillary water [42]. These results are supported by an experiment that showed a reduced WSC in the mixture of bryophytes with different life forms and water uptake system [43]. 
In comparison, the results of this study demonstrated no statistical differences in $\mathrm{WSC}_{\mathrm{f}}$-quadrat/WSC $\mathrm{d}_{\mathrm{d}}$-quadrat values between substrates, nor any change in these values with altitude (Figure 3). This is because logs largely covered by bryophytes were almost decayed and the surface material was similar to that of humus soil. These similarities in substrate surface could result in the development of similar bryophyte communities between logs and the soil. Furthermore, the differences of dominant bryophytes along the altitudinal gradient were less clear at the study sites, as several species occurred at a wider altitudinal range (e.g., Hyl spl; 1800-2600 m, and Ple shr; 1800-2600 m), which could reduce the magnitude of change to the WSC-quadrat with altitude.

\subsection{Influence of Forest Floor Bryophytes on Below Ground Processes}

The values of $\mathrm{WSC}_{\mathrm{f}}$-quadrat/WSC $\mathrm{d}_{\mathrm{d}}$-quadrat were positively correlated with soil moisture. An increase in soil moisture by bryophyte cover has been reported because the evapotranspiration rate of bryophytes is lower than that of grasses [31] and they are able to retain a large amount of water during wet periods $[44,45]$. In addition, this study suggests that bryophytes with higher WSC have a larger influence on the increase in soil moisture. This influence could be related to the transport of larger amounts of moisture from bryophytes with higher WSC to the soil surface during evapotranspiration processes. Besides, bryophytes with higher WSC might further reduce water evaporation from the soil surface, as these bryophytes often retained water for longer periods [29].

\subsection{Water Storage Capacity at the Substrate/Plot Scale}

The WSC values of bryophytes were affected by biomass (plant tissues mass), species type, and growth form $[29,43]$; however, the constructed liner models revealed that the values of the $\mathrm{WSC}_{\mathrm{f}}$-substrate/WSC $\mathrm{d}_{\mathrm{d}}$-substrate were largely dependent on total bryophyte cover on each substrate, regardless of the type of species and their substrates. These results are explained by the large differences in bryophyte cover among the study plots $\left(24.70 \pm 18.86 \mathrm{~m}^{2} / 100 \mathrm{~m}^{2}\right)$, which decrease the relative influence of other factors (e.g., bryophyte community type) on biomass and makes cover a useful substitute for biomass and the associated WSC-plot.

Due to this strong significant correlation in bryophyte cover with biomass, the altitudinal patterns of the $\mathrm{WSC}_{\mathrm{f}}$-plot/ $\mathrm{WSC}_{\mathrm{d}}$-plot closely fitted a negative quadratic curve (E trail) or a linear regression ( $\mathrm{W}$ trail), with the highest values in subalpine forests where the highest bryophyte cover was recorded (Figure 4). In general, bryophyte cover on the forest floor changes with altitude. Subalpine conifer forests had higher cover due to the favorable environment for bryophyte growth, such as low temperature and high occurrence of fog, and less influence from fallen leaves [46]. In contrast, bryophyte cover tends to decline in temperate broadleaved forests because fallen leaves shade bryophytes on the forest floor and inhibit their photosynthesis [35]. A decline in bryophyte cover has also been reported in alpine zones due to the lack of forest canopies to provide suitable habitats for bryophytes [36].

Interestingly, the plots with the highest WSC-plot values differed between fresh (WSC $\mathrm{W}_{\mathrm{f}}$-plot) and dried samples ( $\mathrm{WSC}_{\mathrm{d}}$-plot) on both $\mathrm{E}$ and $\mathrm{W}$ trails (Table 3). These differences were attributed to larger differences between $\mathrm{WSC}_{\mathrm{f}}$-quadrat and $\mathrm{WSC}_{\mathrm{d}}$-quadrat in endohydric species (Polytrichaceae $\mathrm{sp}$.). Despite the bryophyte samples being collected during the dry period (no rainfall), endohydric species still had higher water retention status because they absorb water from the soil; whereas the water content of ectohydric species was severely reduced. This retained water was completely lost during the oven-drying process, which increased the amount of water absorbed by the dry samples of endohydric species compared to ectohydric bryophytes. These differences in WSC between fresh and dry samples should be carefully considered when one estimates the WSC of bryophytes under field conditions, as the estimated WSC of endohydric bryophytes might be relatively higher than that of ectohydric species if dried samples are used for the calculation.

Due to the higher cover by bryophytes in subalpine forests, the estimated $\mathrm{WSC}_{\mathrm{d}}$-plot had a maximum of $2.5 \mathrm{~mm}$ extra rainfall interception (Table 3), which was almost equivalent to the values 
reported for the WSC of epiphytic bryophytes on trees in montane cloud forests $(3.0-3.5 \mathrm{~mm})[23,25]$. These results underline the importance of forest floor bryophytes for the overall hydrological processes of subalpine forests. Furthermore, considering the influence of snowmelt and cloud water deposition on these bryophytes, their contribution to forest hydrology could be more significant than expected from their interception of additional rainfall alone. Snow pack is a key factor that determines the water dynamics in subalpine forests [47]. After thawing of snow, forest floor bryophytes absorb snowmelt and affect forest soil hydrology by increasing soil infiltration [48]. Like snow packs, cloud water deposition is an important water supply for forests at higher altitude, due to the frequent occurrence of fog [49]. Therefore, forest floor bryophytes, especially ectohydric species that largely rely on atmospheric water, might contribute to the water cycle in this ecosystem through the interception of fog and dew.

\subsection{Changes to Water Storage Capacity by Climatic Change}

Regarding the forest water storage for which bryophytes are responsible, the influence of climate warming might be more serious in subalpine forests where bryophyte WSC showed highest values (Figure 4). Given that global environmental changes seem to affect ecosystems more strongly at the community level than at the individual species level [50], the structure of bryophyte communities is more strongly influenced by climate warming than the species level [43]. For example, severe drought stress caused by climate warming [51] might facilitate the dominance of endohydric $\mathrm{T}$ form species (e.g., Pog jap) over ectohydric W form species (e.g., Hyl spl); because these $\mathrm{T}$ form species can be less affected by drought stress owing to their capacity to absorb water from soil. However, as this study revealed, these changes in the structure of bryophyte communities (i.e., dominant life form types and their interactions) influence the WSC, which also affects the soil moisture that determines soil carbon and nitrogen cycling [52,53]. Hence, climate warming might strongly affect bryophyte WSC controlled by life forms, further causing changes to the biological activity and nutrient cycling of soil in forest ecosystems.

\section{Conclusions}

The bryophyte WSC-plot changed with altitude and was highest in subalpine forests. This altitudinal pattern was explained by bryophyte cover, which could be used as a substitute for bryophyte biomass and its associated WSC. At the quadrat scale, the WCS of bryophytes was related to life form type and their interactions. The WSC further had a positive impact on soil moisture important for soil biological activities. Of importance, bryophyte WSC controlled by the life forms might be strongly affected by climate warming. Thus, changes to the dominance of bryophyte life forms might serve as an early indicator of how bryophyte WCS and associated biological activities are influenced by climate warming.

Funding: This research was supported by the Japan Society for the Promotion of Science-Grant-in-Aid for Young Scientists (B) (grant number 24710029) and Grant-in-Aid for Scientific Research (C) (grant number 16K00566).

Conflicts of Interest: The author declares no conflict of interest.

\section{References}

1. Vose, J.M.; Sun, G.; Ford, C.R.; Bredemeier, M.; Otsuki, K.; Wei, X.; Zhang, Z.; Zhang, L. Forest ecohydrological research in the 21st century: What are the critical needs? Ecohydrology 2011, 4, 146-158. [CrossRef]

2. Brown, A.E.; Zhang, L.; McMahon, T.A.; Western, A.W.; Vertessy, R.A. A review of paired catchment studies for determining changes in water yield resulting from alterations in vegetation. J. Hydrol. 2005, 310, $28-61$. [CrossRef]

3. Farley, K.A.; Jobbagy, E.G.; Jackson, R.B. Effects of afforestation on water yield: A global synthesis with implications for policy. Glob. Chang. Biol. 2005, 11, 1565-1576. [CrossRef] 
4. Postel, S.L.; Thompson, B.H. Watershed protection: Capturing the benefits of nature's water supply services. Nat. Resour. Forum 2005, 29, 98-108. [CrossRef]

5. Guo, Z.; Xiao, X.; Gan, Y.; Zheng, Y. Ecosystem functions, services and their values-A case study in Xingshan County of China. Ecol. Econ. 2001, 38, 141-154. [CrossRef]

6. Mashayekhi, Z.; Panahi, M.; Karami, M.; Khalighi, S.; Malekian, A. Economic valuation of water storage function of forest ecosystems (case study: Zagros Forests, Iran). J. For. Res. 2010, 21, 293-300. [CrossRef]

7. Ataroff, M.; Rada, F. Deforestation impact on water dynamics in a Venezuelan Andean cloud forest. AMBIO 2000, 29, 440-444. [CrossRef]

8. Keim, R.F.; Skaugset, A.E.; Weiler, M. Storage of water on vegetation under simulated rainfall of varying intensity. Adv. Water Resour. 2006, 29, 974-986. [CrossRef]

9. Veneklaas, E.J.; Zagt, R.; Van Leerdam, A.; Van Ek, R.; Broekhoven, A.; Van Genderen, M. Hydrological properties of the epiphyte mass of a montane tropical rain forest, colombia. Vegetatio 1990, 89, 183-192. [CrossRef]

10. Zhang, L.; Wang, J.; Bai, Z.; Lv, C. Effects of vegetation on runoff and soil erosion on reclaimed land in an opencast coal-mine dump in a loess area. Catena 2015, 128, 44-53. [CrossRef]

11. Le Bissonnais, Y.; Lecomte, V.; Cerdan, O. Grass strip effects on runoff and soil loss. Agronomie 2004, 24, 129-136. [CrossRef]

12. Chamizo, S.; Cantón, Y.; Rodríguez-Caballero, E.; Domingo, F.; Escudero, A. Runoff at contrasting scales in a semiarid ecosystem: A complex balance between biological soil crust features and rainfall characteristics. J. Hydrol. 2012, 452-453, 130-138. [CrossRef]

13. Belnap, J. The potential roles of biological soil crusts in dryland hydrologic cycles. Hydrol. Process. 2006, 20, 3159-3178. [CrossRef]

14. Sala, O.E.; Chapin, F.S.; Armesto, J.J.; Berlow, E.; Bloomfield, J.; Dirzo, R.; Huber-Sanwald, E.; Huenneke, L.F.; Jackson, R.B.; Kinzig, A. Global biodiversity scenarios for the year 2100. Science 2000, 287, 1770-1774. [CrossRef] [PubMed]

15. Root, T.L.; Price, J.T.; Hall, K.R.; Schneider, S.H.; Rosenzweig, C.; Pounds, J.A. Fingerprints of global warming on wild animals and plants. Nature 2003, 421, 57-60. [CrossRef] [PubMed]

16. Creed, I.F.; Spargo, A.T.; Jones, J.A.; Buttle, J.M.; Adams, M.B.; Beall, F.D.; Booth, E.G.; Campbell, J.L.; Clow, D.; Elder, K.; et al. Changing forest water yields in response to climate warming: Results from long-term experimental watershed sites across North America. Glob. Chang. Biol. 2014, 20, 3191-3208. [CrossRef] [PubMed]

17. Chen, I.-C.; Hill, J.K.; Ohlemüller, R.; Roy, D.B.; Thomas, C.D. Rapid range shifts of species associated with high levels of climate warming. Science 2011, 333, 1024-1026. [CrossRef] [PubMed]

18. Gonzalez, P.; Neilson, R.P.; Lenihan, J.M.; Drapek, R.J. Global patterns in the vulnerability of ecosystems to vegetation shifts due to climate change. Glob. Ecol. Biogeogr. 2010, 19, 755-768. [CrossRef]

19. Proctor, M.C.; Tuba, Z. Poikilohydry and homoihydry: Antithesis or spectrum of possibilities? New Phytol. 2002, 156, 327-349. [CrossRef]

20. He, X.; He, K.S.; Hyvönen, J. Will bryophytes survive in a warming world? Perspect. Plant. Ecol. Evol. Syst. 2016, 19, 49-60. [CrossRef]

21. Oishi, Y. Urban heat island effects on moss gardens in Kyoto, Japan. Lands. Ecol. Eng. 2018. [CrossRef]

22. Pypker, T.G.; Unsworth, M.H.; Bond, B.J. The role of epiphytes in rainfall interception by forests in the Pacific Northwest. I. Laboratory measurements of water storage. Can. J. For. Res. 2006, 36, 809-818. [CrossRef]

23. Pócs, T. The epiphytic biomass and its effect on the water balance of two rain forest types in the Uluguru Mountains (Tanzania, East Africa). Acta Bot. Acad. Sci. Hung. 1980, 26, 143-167.

24. Hölscher, D.; Köhler, L.; van Dijk, A.I.; Bruijnzeel, L.S. The importance of epiphytes to total rainfall interception by a tropical montane rain forest in Costa Rica. J. Hydrol. 2004, 292, 308-322. [CrossRef]

25. Ah-Peng, C.; Cardoso, A.W.; Flores, O.; West, A.; Wilding, N.; Strasberg, D.; Hedderson, T.A.J. The role of epiphytic bryophytes in interception, storage, and the regulated release of atmospheric moisture in a tropical montane cloud forest. J. Hydrol. 2017, 548, 665-673. [CrossRef]

26. Chang, S.-C.; Lai, I.-L.; Wu, J.-T. Estimation of fog deposition on epiphytic bryophytes in a subtropical montane forest ecosystem in Northeastern Taiwan. Atmos. Res. 2002, 64, 159-167. [CrossRef] 
27. Köhler, L.; Tobón, C.; Frumau, K.A.; Bruijnzeel, L.S. Biomass and water storage dynamics of epiphytes in old-growth and secondary montane cloud forest stands in Costa Rica. Plant. Ecol. 2007, 193, 171-184. [CrossRef]

28. Michel, P.; Payton, I.J.; Lee, W.G.; During, H.J. Impact of disturbance on above-ground water storage capacity of bryophytes in New Zealand indigenous tussock grassland ecosystems. N. Z. J. Ecol. 2013, 114-126.

29. Elumeeva, T.G.; Soudzilovskaia, N.A.; During, H.J.; Cornelissen, J.H. The importance of colony structure versus shoot morphology for the water balance of 22 subarctic bryophyte species. J. Veg. Sci. 2011, 22, 152-164. [CrossRef]

30. Easterling, D.R.; Meehl, G.A.; Parmesan, C.; Changnon, S.A.; Karl, T.R.; Mearns, L.O. Climate extremes: Observations, modeling, and impacts. Science 2000, 289, 2068-2074. [CrossRef] [PubMed]

31. Zimov, S.A.; Chuprynin, V.; Oreshko, A.; Chapin III, F.; Reynolds, J.; Chapin, M. Steppe-tundra transition: A herbivore-driven biome shift at the end of the Pleistocene. Am. Nat. 1995, 146, 765-794. [CrossRef]

32. Hobbie, S.E.; Schimel, J.P.; Trumbore, S.E.; Randerson, J.R. Controls over carbon storage and turnover in high-latitude soils. Glob. Chang. Biol. 2000, 6, 196-210. [CrossRef]

33. Tan, B.C.; Iwatsuki, Z. Hot spots of mosses in East Asia. Anal. Inst. Biol. Ser. Bot. 1996, 67, 159-167.

34. Geffert, J.L.; Frahm, J.-P.; Barthlott, W.; Mutke, J. Global moss diversity: Spatial and taxonomic patterns of species richness. J. Bryol. 2013, 35, 1-11. [CrossRef]

35. Sun, S.-Q.; Wu, Y.-H.; Wang, G.-X.; Zhou, J.; Yu, D.; Bing, H.-J.; Luo, J. Bryophyte species richness and composition along an altitudinal gradient in Gongga Mountain, China. PLoS ONE 2013, 8, e58131. [CrossRef] [PubMed]

36. Grau, O.; Grytnes, J.A.; Birks, H. A comparison of altitudinal species richness patterns of bryophytes with other plant groups in Nepal, Central Himalaya. J. Biogeogr. 2007, 34, 1907-1915. [CrossRef]

37. Japan Meteorological Agency. Past Meteorological Data (Nobeyama). Available online: http:/ / www.data.jma.go.jp/obd/stats/etrn/view/nml_amd_ym.php?prec_no=48\&block_no=0415\& year=\&month $=\&$ day $=\& v i e w=($ accessed on 12 April 2018).

38. Japan Meteorological Agency. Top Ten in Recorded History. Available online: http://www.data.jma. go.jp /obd/stats / etrn/view /rank_a.php?prec_no=48\&block_no=0415\&year=\&month=\&day=\&view= (accessed on 12 April 2018).

39. Oishi, Y. Comparison of moss and pine needles as bioindicators of transboundary polycyclic aromatic hydrocarbon pollution in central japan. Environ. Pollut. 2018, 234, 330-338. [CrossRef] [PubMed]

40. Bates, J. Is life-form a useful concept in bryophyte ecology? Oikos 1998, 223-237. [CrossRef]

41. R Core Team. R: A Language and Environment for Statistical Computing; R Foundation for Statistical Computing: Vienna, Austria, 2018; Available online: http:/ / www.R-project.org/ (accessed on 12 April 2018).

42. Proctor, M.C. The bryophyte paradox: Tolerance of desiccation, evasion of drought. Plant. Ecol. 2000, 151, 41-49. [CrossRef]

43. Michel, P.; Lee, W.G.; During, H.J.; Cornelissen, J.H.C. Species traits and their non-additive interactions control the water economy of bryophyte cushions. J. Ecol. 2012, 100, 222-231. [CrossRef]

44. Maestre, F.T.; Huesca, M.; Zaady, E.; Bautista, S.; Cortina, J. Infiltration, penetration resistance and microphytic crust composition in contrasted microsites within a Mediterranean semi-arid steppe. Soil Biol. Biochem. 2002, 34, 895-898. [CrossRef]

45. Eldridge, D.; Rosentreter, R. Morphological groups: A framework for monitoring microphytic crusts in arid landscapes. J. Arid Environ. 1999, 41, 11-25. [CrossRef]

46. Nakatsubo, T. The role of bryophytes in terrestrial ecosystems with special reference to forests and volcanic deserts. Jpn. J. Ecol. 1997, 47, 43-54. [CrossRef]

47. LaMalfa, E.M.; Ryle, R. Differential snowpack accumulation and water dynamics in aspen and conifer communities: Implications for water yield and ecosystem function. Ecosystems 2008, 11, 569-581. [CrossRef]

48. Beringer, J.; Lynch, A.H.; Chapin, F.S., III; Mack, M.; Bonan, G.B. The representation of arctic soils in the land surface model: The importance of mosses. J. Clim. 2001, 14, 3324-3335. [CrossRef]

49. Kalina, M.F.; Stopper, S.; Zambo, E.; Puxbaum, H. Altitude-dependent wet, dry and occult nitrogen deposition in an alpine region. Environ. Sci. Pollut. Res. 2002, 9, 16-22. [CrossRef]

50. Suding, K.N.; Lavorel, S.; Chapin, F.S.; Cornelissen, J.H.C.; DÍAz, S.; Garnier, E.; Goldberg, D.; Hooper, D.U.; Jackson, S.T.; Navas, M.-L. Scaling environmental change through the community-level: A trait-based response-and-effect framework for plants. Glob. Chang. Biol. 2008, 14, 1125-1140. [CrossRef] 
51. Aiguo, D. Drought under global warming: A review. WIREs Clim. Chang. 2011, 2, 45-65. [CrossRef]

52. Robinson, C.; Wookey, P.; Parsons, A.; Potter, J.; Callaghan, T.; Lee, J.; Press, M.; Welker, J. Responses of plant litter decomposition and nitrogen mineralisation to simulated environmental change in a high arctic polar semi-desert and a subarctic dwarf shrub heath. Oikos 1995, 503-512. [CrossRef]

53. Fisk, M.C.; Schmidt, S.K.; Seastedt, T.R. Topographic patterns of above-and belowground production and nitrogen cycling in alpine tundra. Ecology 1998, 79, 2253-2266. [CrossRef] 